\title{
RESIDENTS' PRIZES
}

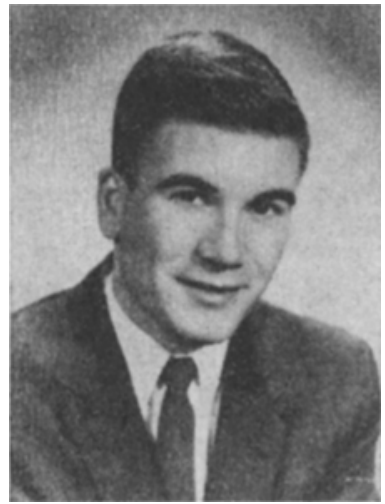

Dr. R. K. Calverley

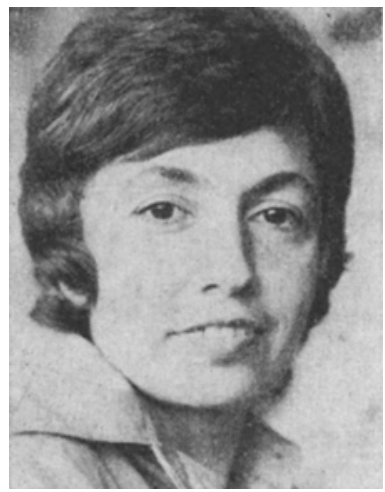

Dr. Hanna Samuloska

Prizes for the best papers in the Residents' Competition at the Annual Meeting of the Canadian Anaesthetists' Society, June 26 to July 2, 1971, were awarded to: Dr. R. K. Calverley, Department of Anaesthesia, University of British Columbia (First Prize), "An Inaesthetic Application of Serum Digoxin Radio-Immunoassay"; Dr. Hanna Samulska, Department of Anaesthesia, University of Toronto (Second Prize), "Unintended Exposure to Halothane in Surgical Patients: Halothane Washout Studies"; Dr. Cosetta Margaria, Department of Anaesthesia, McGill University (Third Prize), "Immediate Response to Eilistic Loads Before and After Epidural Block."

Les prix pour les meilleurs travaux présentés au Concours des Résidents à l'Assemblée anmuelle de la Société Canadienne des Anesthésistes, du 26 juin au 2 juillet 1971, ont été accordés à: Dr. R. K. Calverley, département d'anesthésie, Université de Colombie Britannique (premier prix), "An Anaesthetic Application of Serum Digoxin Radio-Immunoassay"; Dr. Hanna Samulska, département d'anesthésie, Université de Toronto (deuxième prix), "Unintended Exposure to Halothane in Surgical Patients: Halothane Washout Studies"; Dr. Cosetta Margaria, département d'anesthésie de l'Université McGill (troisième prix), "Immediate Response to Elastic Loads Before and After Epidural Block". 